\title{
The Level of Compliance with The Public Procurement Act of Ghana
}

\author{
Soffia Aba Baidoo-Baiden \\ Takoradi Technical University \\ soffiasel@yahoo.co.uk \\ Edward Nii Amar Amarteifio \\ Centre for Entrepreneurship and Small Enterprises Development, \\ School of Business, sE: \\ University of Cape Coast,ist:-ieape Coast, Ghana \\ Email: eamarteifio@ucc.edu.gh \\ DOI: 10.29322/IJSRP.10.03.2020.p9918 \\ http://dx.doi.org/10.29322/IJSRP.10.03.2020.p9918
}

\begin{abstract}
The Public Procurement Act (Act 663) 2003 became law in Ghana to help reduce the irregularities in public procurement. The Act has as its goal the promotion of fairness, transparent procedures in public procurement and nondiscrimination against supplier on any grounds. The implementation of the Act has faced lots of ongoing challenges and has exposed many flaws that it was supposed to address with its inception. This study assessed the level of compliance of procurement entities with the Public Procurement Act. There was a total of 25 ministries in Ghana, out of which 12 ministries were purposively selected. For the assessment of compliance with the key global best practices, the study looked at four core compliance areas namely management systems,

\section{Introduction}

Procurement as a public-sector activity is gradually becoming the tool wield by the central government in ensuring the efficient and responsible utilisation of scarce public funds for development and to guarantee a lean government. Going by this tenet, the functions the procurement as a sector of the public service has changed considerably in the last two decades demanding integrity in government and public procurement in general. Countries increasingly have enacted legislation and made rules and regulations that guarantee fairness and transparency in procurement practices and that public funds are deployed to public procurement in the
\end{abstract}

information and communication, procurement process and contract management. The study revealed that the ministry with the highest compliance level is the Ministry of Finance. The Ministry of Finance had the overall compliance level (38.06\%), followed by the Ministry of Trade and Industry (27.51\%). The Ministry of Youth and Sports had the least level of compliance (11.68\%). This finding affirms conclusively that there is a general low level of compliance to the provisions of the Act. In line with the operational activities of the procurement system in Ghana and at the stage of the implementing agencies mandated for initiating procurement activities, it was concluded that procurement officials were not keeping proper records. Proper accounting procedures were not in place for procurement official.

supreme public good. Adu Sarfo (2011) points out that the bulk of governments revenue goes to the delivery of services via procurement services. It is therefore in the public interest to achieve value for money through planned and orderly processes of acquisition and management of this key government function.

Lloyd and McCue (2004) looks at procurement processes in the public sector as sourcing for goods, services and works from groups and their associated intermediaries to satisfy government and public needs as a whole. In their definition, they added expenditure directed at its citizens on social activities and economic well-being. This is achieved 
ISSN 2250-3153

through formal procurement process involving competitive bidding from the potential vendors. When public procurement is effective, the goals of public sector financial optimisation is realised, thereby achieving good governance in the eyes of the citizens. This is so because procurement forms a big part of government expenditure and much of this comes from the taxes levied in the citizens. In the UK, for instance, it is projected that $£ 150$ billion annually in purchases of goods and services needed to keep the government sector going (Dave, 2009; Ahimbisibwe, 2014). Purchasing of goods and services is normally the phraseology used by firms and individuals in describing their contracting relationships with governments (Lloyd, et al., 2004).

In Ghana, rules for public sector procurement are defined by the Public Procurement Act (663) (henceforth the Act) and supporting regulations promulgated from time to time by the implementing agencies. The rules require, inter alia, that the public procurement system cover procurement planning, qualification of tenders, form of communicating, rejecting of tenders, entry into force the procurement contract award, inducement from supplies, contracting agents and their consultants and specified the official language of transactions.

Public procurement, in any form it takes, is a bigticket item with wider implications for budgeting for the public sectors in terms of public spending and the consumptions of goods and the associated services in a given country. Admittedly, there is not much by way of academic research of the characterisations of public procurement activities in Ghana (with anticipated estimates between 50 percent to 70 percent of total Government expenditures after government salaries and emoluments, accounting for 14 percent of Gross Domestic Product and nearly 24 percent of total imports (Dave, 2009), undoubtedly, a casual observation of the economic activities points at the public sector as the largest customer and so is better positioned to influence competition, governance and socio-economic development of the country. Improving public procurement management in such an environment will no doubt create wealth and reduce poverty. Public procurement, one can say, acts as a channel connecting public requirements of, for example, housing, transportation, educational infrastructure, sanitation, public health and development of
SMEs to private-sector entrepreneurs and providers (Adu Sarfo, 2011 ).

The public procurement reforms can be situated in the broadly in a wider agenda to bring transparency in governance activities in the developing world of which Ghana is a part. Typical goals of the procurement reforms are to optimise national resources to promote national development, to situate procurement activities within the relevant country and global practices, boost competition, transparency and accountability to attain efficiency, promote the ease procurement and attendance administrative procedure and guarantee value for money for the public (Ministry of Finance-Ghana, 2001). Governments discharge its core mandates of ensuring the wellbeing of its citizenry by providing goods and services. The items are attained either internally by government entities or sources external to government within the private sector. Governments in a sense employ the mechanisms of their budgeting process to ensure this approach is optimised, should they decide to produce their needs in-house or, given the wider public, the opportunity to participate through the procurement process, thus meeting the goals of value for money via sourcing of the services and good at the most optimum price in the appropriately needed quantities for use. Further, public procurement in government must be conducted and directed with the objectives of accountability, non-discrimination among potential suppliers and a commitment to globally best practices in mind (Adu Sarfo, 2011 ). Due to this, public procurement is expected to enact the required legislation to define and guide its practice in all countries, in order to protect its interest (Adu Sarfo, 2011 ).

Despite the importance of the Act, government agencies and departments in Ghana go through enormous bureaucratic processes in acquiring goods and services. This, notes Nketia-Asante (2013), leads to waste of public resources with potentially adverse effects on government finances. The Act was expected to improve public finances, instead, it has weakened it. Some vendors in the country have criticised the covert procurement procedures and inordinate long delays in compensation after executing projects, supplied goods or rendered services (World Bank, 2003). By some accounts, the inception of the Act has increased government domestic 
obligations, aside making its management burdensome and reducing potential government investments.

Hence the objective of the study was to find out the level of compliance of public procurement act in Ghana, which was instituted to address some of these observed anomalies.

\section{Literature Review}

Procurement can be seen as a set of planned actions undertaken towards sourcing items for the public sector. It comprises steps of sourcing goods, contracts and related functions, from third supplier entities and/or from given inhouse facilities. A more formal definition given by Linthorst and Telgen (2006) looks at public procurement as any formal arrangement be it through buying, renting, leasing, hire purchasing, licensing, tenancy franchising or any other contracting mechanism available for public usage. The whole process cycle starts with the identifying of specific needs to the closing out of the contractual relationship with the supplier of these goods and services. Entities statutorily established by law are mandated to undertake procurement on behalf of the government (Public Procurement Act, 2003).

Advocates of modern procurement management systems in governance see it as an enabler of economic development. Public units of democracies, multi-lateral donors and other global aid groups all use public procurement as a vehicle to aid and donor relief programs intended to curb diseases, reduce poverty, creating employment, reduction of damaging environmental impact and promoting socioeconomic development (Kashap, 2004). The United Nations Commission on International Law provides an exemplar law aimed at maximising economic effectiveness in procurement and fostering participation in procurement proceedings by small contractors and suppliers with the attending benefits of generating employment and reducing poverty.

One major feature of the approach to compliance with procurement legal norms at the national level is the extent to which governmental authorities adopt tools of enforcement (McCrudden, 2007). Many governments in developing countries rely extensively on regulations as the basic controlling mechanism in public procurement policy implementation. This is particularly so in countries with the dominant political concerns as the principles of openness and accountability in public procurement management (Schapper, et al., 2006). In this regard, Hunja (2003) write that several countries have instituted reforms aimed at strengthening procurement sectors, promoting competition, openness, efficiency, and ensuring accountability.

According to OECD (2003), a strict commitment to public procurement legislation is vital to judicious utilisation of public funds to achieve development goals. Crucially, a commitment to rigorously enforcing the rules of public procurement and non-discriminatory application of sanctions against erring entities transparently is vital to the operations of an acceptable procurement regime. In the words of Osei-Tutu et al. (2010), it is when enforcement measures are implemented that the reform objectives stated above can be achieved. Adhering to procurement provisions is vital in the achievement of policy objectives. The authors identify that where procurement regulation objectives are not accompanied by strict enforcement and compliance measures, the policy objectives gradually ground to a failure.

OECD (2003) reports that a rational for procurement activities in the three East African countries are disrupted as a result of legal frameworks that are ambiguous, unenforced, not complied with, and hence have been ineffective to ensure efficient and cost-effective purchases. No doubt, the procurement reforms in Kenya, Tanzania and Uganda have focussed more on legislative enforcement. The Public Finance Act 2001 and Public Procurement Act of Tanzania for example, provide clear enforcement mechanisms and specifies clearly sanctions for non-adherence to the provisions of the Act. Osei-Tutu et al. (2010) argue that an inflexible compliance mechanism can lead to process sidestepping. For instance, a strict expedited procurement process might circumvent the transparency of the processes, achieving goals of efficiency but opening the process to administrative corruption.

According to the writers, what is more important in ensuring a high level of compliance is the permanent monitoring of procurement supervision. Control, therefore, plays a key role in procurement enforcement. It is essential for a procurement unit to have frequent external audits including Compliance/Performance Indicators (CPIs) to ensure higher compliance. In Kenya for example, the Public Procurement 
Oversight Authority (2007) reports that lax enforcement and follow through on external audit findings account for inefficient and often lengthy mis-procurement corrective actions. This view is supported by Pegnato (2003) that a rigid enforcement framework is not responsive to the needs of the entities and so defeats the goals of efficiency and flexibility in procurement.

The EU Public-Sector Remedies Directive as captured in Gelderman et al. (2006) maintains the inadequacy of existing remedies at the national level to ensure compliance and enforcement of the public procurement actions is usually shown by the inability of governments to correct infringements and ensure a strict adherence to the rules defining procurement in the public services. The enactment of subsidiary directives to deepen decentralisation ensures efficiency by bringing procurement activities to every

Table 1: Rating of Compliance

district. This has helped to address disparities in the urban and suburban SMEs access to opportunities of participating in the procurement processes and increased competition in pricing thus lowering the overall cost and increasing the offering of products available to the public sector. While conceding that the country's courts are not directly involved in crafting procurement legislation, Thai (2001) reaffirms the importance of the judiciary in enforcing compliance through the adjudication of contract disputes. This process is vital as it inspires the confidence of all parties in the process.

With regards to this research, the PPA is mandated by Sections 3(d) 13(e) and 3(h) of the Act (2003) to evaluate the performance of the various units under its purview to ensure adherence to the specifications of the Act. This research intends to ascertain whether public entities comply with the regulatory framework of the procurement reform. To achieve this, the rating of compliance by the World Bank/OECD/DAC was adopted.

\begin{tabular}{|c|c|c|}
\hline Compliance & $\begin{array}{l}\text { Key Compliance } \\
\text { Indicators }\end{array}$ & Information rated on a scale of $0-5$ \\
\hline \multirow{14}{*}{ Management Systems } & \multirow{3}{*}{ Effective Leadership } & Seeking technical support from the body with oversight role \\
\hline & & Carrying out internal procurement auditing \\
\hline & & Good record keeping \\
\hline & \multirow{3}{*}{$\begin{array}{l}\text { Human Resources } \\
\text { Development }\end{array}$} & Having Staff with professional procurement qualification \\
\hline & & Putting internal auditors in place and giving them procurement training \\
\hline & & Evaluation of performance of procurement staff \\
\hline & \multirow{4}{*}{$\begin{array}{l}\text { Monitoring and Control } \\
\text { Systems }\end{array}$} & Putting proper payment systems in place for every contract \\
\hline & & Capturing procurement transactions in Cash budgets \\
\hline & & Putting in place quality control mechanisms for contracts \\
\hline & & Effective use of available procurement information dissemination \\
\hline & \multirow{3}{*}{$\begin{array}{l}\text { Compliance with ethics } \\
\text { and } \quad \text { regulatory } \\
\text { framework }\end{array}$} & Appropriate use of procurement plans and contract documents \\
\hline & & Use of Standard Tender Documents (STD) and Manuals \\
\hline & & Use of right procurement methods \\
\hline & $\begin{array}{l}\text { Complaints system, } \\
\text { structure and sequence }\end{array}$ & $\begin{array}{l}\text { Fairness and transparency in resolution of cases within the terms } \\
\text { established in the legal framework }\end{array}$ \\
\hline \multirow{3}{*}{$\begin{array}{l}\text { Information } \\
\text { Communication }\end{array}$} & \multirow{2}{*}{$\begin{array}{l}\text { Procurement } \\
\text { Information searching } \\
\text { and Dissemination }\end{array}$} & $\begin{array}{l}\text { Awareness of use procurement website, procurement internal notice boards } \\
\text { and newspapers }\end{array}$ \\
\hline & & $\begin{array}{l}\text { Capacity to use and using the procurement information dissemination } \\
\text { systems }\end{array}$ \\
\hline & Interaction with the & Having knowledge of and interacting with the marketplace \\
\hline
\end{tabular}




\begin{tabular}{|c|c|c|}
\hline & marketplace & Interacting with all procurement stakeholders \\
\hline \multirow{17}{*}{ Procurement processes } & \multirow{2}{*}{ Procurement Planning } & Having an adequately defined procurement plan \\
\hline & & Posting plan on the net \\
\hline & \multirow{3}{*}{ Procurement Publicity } & Advertising tender invitations \\
\hline & & Sending information for placement in procurement bulletin \\
\hline & & Using internal notice boards to display procurement information \\
\hline & \multirow{3}{*}{$\begin{array}{l}\text { Bid Preparation and } \\
\text { Invitation }\end{array}$} & Use of STDs \\
\hline & & All bid documents containing same evaluation criteria \\
\hline & & Stating reasonable date and time for bid opening \\
\hline & \multirow{6}{*}{$\begin{array}{l}\text { Submission, opening } \\
\text { and evaluation of bids }\end{array}$} & Stating date, time and venue for bid submission \\
\hline & & Stating date, time and venue for bid opening \\
\hline & & Having secured tender box in place \\
\hline & & Having tender opening register \\
\hline & & Keeping minutes of bid opening including all opening records \\
\hline & & Evaluating tenders in accordance with tendering requirements \\
\hline & \multirow{3}{*}{ Award of Contract } & Notifying Winner of Contract \\
\hline & & Publicising contract awards \\
\hline & & Notifying losers of bid \\
\hline \multirow{11}{*}{ Contract Management } & \multirow{2}{*}{$\begin{array}{l}\text { Project Planning and } \\
\text { Mobilisation }\end{array}$} & Taking Works Programme from executers \\
\hline & & Taking Advance payment Guarantees for advance payments made \\
\hline & \multirow{3}{*}{$\begin{array}{l}\text { Project Implementation } \\
\text { and Supervision }\end{array}$} & Preparation of project monitoring reports \\
\hline & & Organisation of project progress meetings \\
\hline & & Comparing and analysing planned progress against actual \\
\hline & \multirow{3}{*}{$\begin{array}{l}\text { Inspection and } \\
\text { Inventory control }\end{array}$} & Preparation of completion or delivery reports \\
\hline & & Preparation of Handing over certificates \\
\hline & & Use of appropriate stock control record system \\
\hline & \multirow{3}{*}{ Disposal } & Forming the required membership of Board of survey \\
\hline & & Keeping minutes of meetings of Board of survey \\
\hline & & Keeping records of items disposed \\
\hline
\end{tabular}

Source: World Bank/OECD/DAC (2005)

\section{Methodology}

For the assessment of compliance with the key global best practices, the study looked at four core compliance areas. A select number of indicators were used to assess the compliance with the levels. Baseline data quality and availability remains a key challenge in much of the developing world with Ghana being a case in point. As a result, we considered only four main aspects of compliance to the procurement protocols. The determination or assessment of compliance levels was determined by administering structured questionnaires. There was a total of 25 ministries in Ghana (Ghana Statistical
Service, 2014), out of which 12 ministries were purposively selected. The research was limited to 12 MDAs out of 25 MDAs. These MDAs were purposively selected for this study based on being perceived as not being active. Generalisation of the level of compliance is therefore limited to the 12 selected MDAs. Compliance assessment

\section{Table 2: Level of Compliance}

means adopted for this study came from the Public Procurement Authority; hence any limitations they were exposed to affected this study. The data collection was hampered by the close-ended questionnaire. This, it has been 
noted as limiting the amount of data collected. In all probability, relevant data might have escape the attention of the researcher. This caveat must be present in any research involving a close-ended questionnaire. That notwithstanding, the results are thought provoking and can be regarded as a basis for more detailed and analytical work on the topic in future.

\section{Analysis and Discussion of results}

The summary statistics in Table 2 indicated low levels of compliance in the Ministries. The procurement systems had a good mechanism in place compared to the other three main areas of compliance. The ministries showed a persistently low levels of compliance with none attaining 50 percent in all the four key compliance areas (see Table 2).

\begin{tabular}{|c|c|c|c|c|c|}
\hline Name of Ministry & $\begin{array}{l}\text { Management } \\
\text { Systems }\end{array}$ & $\begin{array}{l}\text { Information } \\
\text { Communication }\end{array}$ & $\begin{array}{l}\text { Procurement } \\
\text { Process }\end{array}$ & $\begin{array}{l}\text { Contract } \\
\text { Management }\end{array}$ & Total \\
\hline Ministry of Education & 30.57 & 15.00 & 7.90 & 9.30 & 15.69 \\
\hline Ministry of Youth and Sports & 15.00 & 10.32 & 12.98 & 8.40 & 11.68 \\
\hline Ministry of Health & 15.00 & 20.00 & 33.70 & 12.67 & 20.34 \\
\hline $\begin{array}{l}\text { Ministry of Lands and Natural } \\
\text { Resources }\end{array}$ & 28.50 & 1.37 & 14.50 & 2.70 & 11.77 \\
\hline $\begin{array}{l}\text { Ministry of Employment and } \\
\text { Social Welfare }\end{array}$ & 29.72 & 8.90 & 27.80 & 5.89 & 18.08 \\
\hline Ministry of Transport & 38.53 & 13.10 & 22.84 & 16.00 & 22.62 \\
\hline $\begin{array}{l}\text { Ministry of Envt, Sci, Tech } \\
\text { and Innovation }\end{array}$ & 21.20 & 12.58 & 25.40 & 12.00 & $\mathbf{1 7 . 8 0}$ \\
\hline $\begin{array}{l}\text { Ministry of Works and } \\
\text { Housing }\end{array}$ & 28.90 & 14.00 & 30.40 & 13.51 & 21.70 \\
\hline Ministry of Finance & 35.30 & 28.53 & 55.70 & 32.70 & 38.06 \\
\hline $\begin{array}{llll}\text { Ministry of } & \text { Trade } & \text { and } \\
\text { Industry } & & & \\
\text { Ministry of } & \text { Energy } & \text { and }\end{array}$ & 30.00 & 18.00 & 40.92 & 21.11 & 27.51 \\
\hline $\begin{array}{l}\text { Petroleum } \\
\begin{array}{l}\text { Ministry of Roads and } \\
\text { highways }\end{array}\end{array}$ & $\begin{array}{l}28.45 \\
8.50\end{array}$ & $\begin{array}{l}23.90 \\
6.40\end{array}$ & $\begin{array}{l}38.50 \\
23.00 \\
\end{array}$ & $\begin{array}{l}29.80 \\
15.85 \\
\end{array}$ & $\begin{array}{r}30.16 \\
13.44 \\
\end{array}$ \\
\hline Overall Compliance & 25.81 & 14.34 & 27.80 & 14.99 & 20.74 \\
\hline
\end{tabular}

compliance was higher than education. Admittedly, the education sector is unique with its numerous schools purchasing a lot of low value consumables. Again, qualified

The ministry with the highest compliance level is the Ministry of Finance. It is noted that the compliance levels of Ministry of Finance were consistently higher, an indication of that ministry as a pipeline for most public construction works which requires a higher knowledge of the provisions of the Act. Some engagements such as supply of furniture for schools were also contracted through the municipal and district assemblies. It was established that contracts for the construction of hospitals are mostly performed through the MMDAs.

The Ministry of Finance had the overall compliance level (38.06\%), followed by the Ministry of Trade and Industry $(27.51 \%)$. The Ministry of Youth and Sports had the least level of compliance (11.68\%). Overall the health sector's staff are not available at the school levels. This responsibility tends to fall on the shoulders of matrons and accounting staff. (Osei-Tutu, et al., 2010).

Information and Communication had the lowest level of compliance $(14.34 \%)$. One reason that can be associated with this could be the lack of connectivity to enable procurement personnel access information on practices over the internet particularly in some remote and newly established districts. This makes it difficult of procurement officials to have access to the procurement website and also interact with other stakeholders. Also, the lack of periodic training for staff of the procurement function, manifested itself through the lack of mastery using the World Wide Web effectively in disseminating contracting related information to bidders. 
The level of compliance to the Act is a determinant of how entities are abiding by the provisions specified in the legislation. Some industry players have argued that the delays in awarding of contracts in Ghana is as a result of the onerous processes the contracts go through. It has been observed that most contract awards are late due to lack of adequate planning during the procurement processes. Sohail and Cavill (2008) attributes the malpractices in the procurement processes to lack of education on the part of officials of the procurement units.

Generally, low compliance with some of the processes including notifying successful bidder, publicizing contract awards, notifying unsuccessful bidders, using internal notice boards to display procurement information and the use of standard tender documents is attributed to inadequate capacity of procurement personnel. In March 2005, The Paris Declaration on Aid Effectiveness highlighted the need to develop the procurement capacity of developing nations (OECD, 2005). At the top of the agenda of the procurement function in developing countries is the training and skilling of procurement managers and contractors in public entities in both practise and the operation of the procurement law.

The procurement system that registered very low level of compliance were contract management and Information Technology. Institutions and entities did not show enthusiasm in integrating contract management and technology. It is obvious that the path to e-procurement was a long way off in terms of preparation of personnel of the procurement function. There is also a general readily available documentation on contracts. Of the institutions surveyed, it was also discovered that reporting from procurement managers related to project implementation and supervision, monitoring, delivery, and disposed items reports and documents on stock control were not generally comprehensive and compliant with the provisions of the law.

\section{Conclusion}

Our assessment is on four main areas of compliance. The overall adherence to the Act's provisions in the Accra Metropolis is 20.74. This show that the compliance level is very low and this confirms other studies by the World Bank and the PPA. This finding affirms conclusively that there is a general low level of compliance to the provisions of the Act.
The public sector with the highest level of compliance was the Ministry of Finance. The Ministry of Youth and Sports had the least level of compliance. Adherence to the Act (2003) by procurement entities remains a big challenge to achieving the goals of accountability, fairness and openness in the public sector in the country. Other area with low levels or in some cases outright noncompliance include invitation to tender and contract awards. This is an area of concern to the researcher. In line with the operational activities of the procurement system in Ghana and at the stage of the implementing agencies mandated for initiating procurement activities, it was concluded that procurement officials were not keeping proper records. Proper accounting procedures were not in place for procurement officials.

\section{References}

Adu Sarfo, P. (2011 ). Assessing the effects of the procurement Act (663) on Public Financial Management in Ashanti Region. Kwame Nkrumah University of Science and Technology. Kumasi-Ghana: Master's dissertation, School of Graduate Studies, Kwame Nkrumah University of Science and Technology. Retrieved from http://ir.knust.edu.gh/bitstream/123456789/2153/1/Ad u\%20Sarfo.pdf

Ahimbisibwe, A. (2014). The Influence of Contractual Governance Mechanisms, Buyer-Supplier Trust, and Supplier Opportunistic Behavior on Supplier Performance. Journal of African Business, 15(2), 8599.

Dave, L. (2009). Guidelines to Procurement under IBRD Loans and IDA Credits. Washington, DC: World Bank.

Gelderman, C., Ghijsen, P., \& Brugman, M. (2006). Public procurement and EU tendering directives-explaining non-compliance. International Journal of Public Sector Management, 19(7), 702-714.

Ghana Statistical Service. (2014). Ghana Living Survey Round 6 Community Facilities. Accra, Ghana: Government of Ghana. Retrieved from http://www.statsghana.gov.gh/docfiles/glss6/GLSS6_ Community\%20Facilities\%20Report.pdf

Hunja, R. R. (2003). Obstacles to public procurement reform in developing countries. In Public Procurement: The Continuing Revolution (pp. 13-22). Kluwer Law International.

Kashap, S. (2004). Public procurement as a social, economic and political policy. International Public Procurement Conference Proceedings (October), (pp. 133-147).

Linthorst, M., \& Telgen, J. (2006). Public purchasing future: Buying from multiple suppliers. In Challenges in Public Procurement: An International Perspective (pp. 471-482, 3). 
Lloyd, R. E., \& McCue, C. P. (2004). What is public procurement? Definitional problems and implications. International Public Procurement Conference Proceedings (October), (pp. 2-18).

McCrudden, C. (2007). Corporate social responsibility and public procurement.

Ministry of Finance-Ghana. (2001). Procurement Reform Proposals. A component of the Public Financial Management Reform Programme. Accra, Ghana: Assembly Press.

Nketia-Asante, E. (2013). Expedite action on review of procurement law. Retrieved from http://www.ghanaweb.com/ GhanaHomePage/ regional/artik el.php? $\mathrm{ID}=168235$

OECD-DAC/World Bank. (2005). Organization for Economic Committe Development/Development Assistance Committee(DAC)/World Bank. Guidelines and Reference Series. A DAC Reference Document Harmonising Donor Practices for Effective Aid Delivery, Version 3: Strengthening Procurement Practices in Development Countries.

OECD; World Bank. (2003). International Benchmarks and Standards for public Procurement Systems. Session 2: Priorities, benchmarks and Standards for Good Procurement. OECD/DAC-World Bank Roundtable 22-23 January 2003 (pp. 1-28). Paris: World Bank. Retrieved from http://www.oecd.org/officialdocuments/publicdisplay documentpdf/?cote=DCD/DAC(2003)3\&docLanguag $\mathrm{e}=\mathrm{En}$

OECD. (2005). Paris declaration on aid effectiveness. Paris: OECD. Retrieved from http://www1.worldbank.org/harmonization/Paris/FIN ALPARISDECLARATION.pdf

Osei-Tutu, E., Badu, E., \& Owusu-Manu, D. (2010). Exploring corruption practices in public procurement of infrastructural projects in Ghana. International Journal of Managing Projects in Business, 3(2), 236256.

Pegnato, J. A. (2003). Assessing federal procurement reform: Has the procurement pendulum stopped swinging? Journal of public procurement, 3(2), 145-175.

Public Procurement Act. (2003). The Republic of Ghana.

Public Procurement Oversight Authority. (2007). Assessment of the Procurement System in Kenya. Nairobi, Kenya.

Schapper, P. R., Veiga Malta, J. N., \& Gilbert, D. L. (2006). An analytical framework for the management and reform of public procurement. Journal of public procurement, $6(1 / 2), 1-26$.

Sohail, M., \& Cavill, S. (2008). Accountability to prevent corruption in construction projects. Journal of Construction Engineering and Management 134, 9 , 729-738.

Thai, K. (2001). Public Procurement Re-examined. Journal of Public Procurement, 1(1), 9-50.

Thai, K. (2009). International Handbook of Public Procurement. Boca Raton: Taylor and Francis.

World Bank. (2003). Ghana - Country procurement assessment report : Executive summary (English). Washington, DC : World Bank. 